\title{
Quo vadis with vulnerable defendants in the EU?
}

A closer look at the recent initiatives for procedural safeguards for vulnerable suspects and offenders. The equivocality of the Union's approach effectuating Measure E and the need for an adequate policy towards mentally impaired defendants.

Author: Michaël Meysman ${ }^{1}$

\section{Author contact details:}

Michaël Meysman

Institute for International Research on Criminal Policy (IRCP)

Ghent University

Universiteitstraat 4

9000 Ghent, Belgium

t.: $+32(0) 92646948$

mob.: +32(0) 494257448

Michael.Meysman@ugent.be

Abstract: In a recent press release of the $27^{\text {th }}$ of November 2013, the European Commission presented a package of five proposals to further strengthen procedural safeguards for citizens in criminal proceedings. Two of these proposals directly stem from the Council Procedural Roadmap's Measure E on the (need for) special safeguards for suspected or accused persons who are vulnerable. Whereas the roadmap envisions improved attention for a vulnerable subject regardless of the origins of this vulnerability - be it due to age, mental or physical condition - the recent proposals indicate a clear differentiation between vulnerability based on the defendant's age on the one hand, and the (adult) defendant's mental or physical capacities on the other hand. As such, a proposal for a Directive for procedural safeguards for children was presented, whereas adult defendants in criminal proceedings had to be satisfied with a non-binding Recommendation. While it may indeed be defended that an accumulation of these sources for diminished capacity is not preferable, the Commission's approach and underlining rationale seem equivocal. This article observes these recent initiatives from a dual viewpoint. First of all, they are looked at against the backdrop of the ongoing debate vis-à-vis mutual recognition and the introduction of auxiliary procedural

\footnotetext{
${ }^{1}$ The author is a PhD Researcher at the Institute for International Research on Criminal Policy (IRCP) of the Ghent University. His research focuses on European Criminal Policy and the position of mentally disordered suspects and offenders in the European Criminal Law.
} 
safeguards. The article, therefore, critically assesses the supposed link between the introduction of minimum procedural standards for a category of defendants which, precisely due to their vulnerability, seems less capable of being involved in criminal proceedings with a cross-border dimension. With the latter still the raison d'être for the mutual recognition principle and the basis for the EU to establish minimum rules, the article argues that the EU drifts further away from its Treaty based competence. Secondly, the Commission's reasoning and subsequent policy choice to divide vulnerability based on the defendant's age is analysed with respect to the indications coming from European policy makers and scholars alike. Without aiming to promote a viewpoint of vulnerability where one cause is hierarchically decisive over the other, the article makes a case for an (equally) adequate instrument for defendants with a mental disorder in criminal proceedings.

Keywords: mutual recognition - procedural minimum rights - vulnerable defendants - age mental condition - measure $\mathrm{E}$

\section{Introduction}

Following the inception of the new $\operatorname{era}^{2}$ of EU policy making in the field of criminal law since the Tampere milestones ${ }^{3}$ and the implementation of the principle of mutual recognition for judicial decisions throughout the EU, many a critical observer has lamented over the EU's criminal justice policy's emphasis on the simplification and acceleration of police and judicial cooperation without consideration for setting an acceptable standard for fundamental rights. ${ }^{4}$ However, from the early conception of mutual recognition on both the Tampere

\footnotetext{
${ }^{2}$ The Tampere Council has clearly indicated mutual recognition as 'the future cornerstone' for judicial cooperation in the EU. Furthermore, various scholars endorse that the introduction and effectuation of the principle has indeed heralded a fundamentally different approach towards EU policy making in the field of criminal law. See, inter alia: I. Bantekas, The Principle of Mutual Recognition in the EU Criminal Law, European Law Review (ELR),32(3), 2007; V. Mitsilegas, The Third Wave of Third Pillar Law. Which Direction for EU Criminal Justice? European Law Review (ELR), 34(4), 2009; G. Vermeulen, Mutual recognition, harmonisation and fundamental (procedural) rights protection, in: M. Martin (Ed.), Crime, rights and the EU: the future of police and judicial cooperation, 2008, pp. 89-104.

${ }^{3}$ European Council, Tampere European Council Presidency Conclusions, 1999. Retrieved from: http://www.consilium.europa.eu/uedocs/cms data/docs/pressdata/en/ec/00200-r1.en9.htm.

${ }^{4}$ See, inter alia: K. Ambos, Mutual recognition versus procedural guarantees? In M. de Hoyos Sancho (Ed.), Criminal proceedings in the European Union: essential safeguards, 2008, pp. 25-38; M. Anderson, Law enforcement cooperation in the EU and fundamental rights protection. In M. Martin (Ed.), Crime, rights and the EU: the future of police and judicial cooperation, 2008, pp. 105-120; E. Cape, J. Hodgson, T. Prakken\& T. Spronken, Suspects in Europe, procedural rights at the investigative stage of the criminal process in the European Union (1 ed. Vol. 64), 2007; Vermeulen(fn. 2), pp. 89-104; G. Vermeulen\& L. van Puyenbroeck, Towards minimum procedural guarantees for the defence in criminal proceedings in the EU. International and Comparative Law Quarterly (ICLQ), 60(04), 2011, pp. 1017-1038.
} 
conclusions ${ }^{5}$ and the Programme of Measures to implement the principle of mutual recognition ${ }^{6}$, it has been indicated that protecting defence rights by procedural safeguards operating to equivalent standards in all member states was seen from the outset as an integral part of the mutual recognition scheme. ${ }^{7}$ Notwithstanding this observation, the majority of the mutual recognition instruments that have emerged over the past decade has shown little consideration for the fundamental defence rights of the person involved. ${ }^{8} \mathrm{With}$ this initial critical response on the instruments ${ }^{9}$ emerging under the mutual recognition umbrella and their lack of attention to fundamental procedural rights, the EU undertook a number of initiatives.

Already in December 2000, the European Commission (the Commission), the Council and the Parliament signed the EU Charter of Fundamental Rights ${ }^{10}$ (Charter, or CFREU) as an important (symbolic) step indicating the EU's consistent commitment to fundamental rights and justice. In 2004, and following an initial Green Paper ${ }^{11}$, the Commission tried to give this commitment a more practical rendering in the field of criminal law by submitting the Proposal for a Council Framework Decision (CFD) on certain procedural rights in criminal proceedings throughout the European Union. ${ }^{12}$ Ambitious as the Proposal was, it was ultimately abandoned in 2007 after years of political disagreement. ${ }^{13}$ With the coming into force of the Lisbon Reform Treaty in $2009^{14}$ - which also means the Fundamental Rights Charter's provisions

\footnotetext{
${ }^{5}$ Tampere Conclusion 30 (fn. 3) invited the Council to establish minimum standards ensuring an adequate level of legal aid in cross-border cases. Conclusion 31 refers to multilingual forms or documents to be used in crossborder court cases. Conclusions 33 and 35 respectively mention facilitation of the judicial protection of individual rights and that the principle of fair trial should not be prejudiced by fast track extradition procedures. Conclusion 40 points out that it seeks to develop measures against crime while protecting freedoms and legal rights of individuals.

${ }^{6}$ Council of the European Union, Programme of measures to implement the principle of mutual recognition of judicial decisions in criminal matters, OJ $2001 \mathrm{~L} \mathrm{C12/10}$. The Programme indicates a number of parameters determining the effectiveness of mutual recognition - amongst which parameter 3 includes mechanisms for safeguarding the rights of (third parties, victims and) suspects and parameter 4 mentions the definition of common minimum standards necessary to facilitate the application of the principle of mutual recognition.

${ }^{7}$ C. Morgan, Le Rapprochement des procédures pénales - Procedural Safeguards. Revue internationale de droit penal (RIDP), 77(2006 1/2), 2007, p. 307.

${ }^{8}$ Already in 2000, Peers criticised that 'the negative legal integration in the [former] third pillar has been unaccompanied by any measure to ensure minimum standards for defence rights. See: S. Peers, EU Justice and Home Affairs Law, Harlow: Pearson Education, 2000, p. 187.

${ }^{9}$ Most notably the 'flagship' Framework Decision on the European Arrest Warrant.

${ }^{10}$ Charter of Fundamental Rights of the European Union. OJ 2000 L C/364.

${ }^{11}$ European Commission, Green Paper on Procedural Safeguards for Suspects and Defendants in Criminal Proceedings throughout the European Union. Brussels: $\operatorname{COM}(2003) 75$ final, 2003. Retrieved from http://eurlex.europa.eu/LexUriServ/site/en/com/2003/com2003_0075en01.pdf.

${ }^{12}$ European Commission, Proposal for a Council Framework Decision on certain procedural rights in criminal proceedings throughout the European Union. COM 328 final, 2004. Retrieved from http://eurlex.europa.eu/LexUriServ/LexUriServ.do?uri=CELEX:52004PC0328:EN:HTML.

${ }^{13}$ Vermeulen \& van Puyenbroeck, ICLQ 2011, p. 1017; C. Morgan,(2012). Where Are We Now With EU Procedural Rights?, European Human Rights Law Review (EHRLR) (4), 2012, p. 428.

${ }^{14}$ Treaty of Lisbon amending the Treaty on European Union and the Treaty establishing the European Community, OJ 2007 C 306/01.
} 
now have a binding legal force ${ }^{15}$ - the EU has taken up its ambition to strive for minimum procedural rights with renewed courage. At a time of declining trust in mutual recognition ${ }^{16}$, the Council, making use of the new legal basis provided by the Lisbon Treaty ${ }^{17}$, came up with a Resolution endorsing a Roadmap for strengthening procedural rights of suspected or accused persons in criminal proceedings. ${ }^{18}$ Based on a step-by-step approach, the Council endorses specific procedural rights in so-called measures. So far, this has resulted in six measures ${ }^{19}$ of which the first four have resulted in three Directives ${ }^{20}$ adopted by the Council and the Parliament. The fifth one, measure $\mathrm{E}$ on the (need for) special safeguards for suspected or accused persons that are vulnerable, has only very recently seen the creation of two separate instruments. With a press release on the $27^{\text {th }}$ of November $2013^{21}$, the Commission presented - as a part of a five-part proposal package - a proposal for a Directive on procedural safeguards for children suspected or accused in criminal proceedings ${ }^{22}$ and a (Commission) Recommendation on procedural safeguards for vulnerable persons suspected or accused in criminal proceedings. ${ }^{23}$ Hence, unlike the previous measures A to D, encapsulated in the three Directives, measure E has developed into two separate instruments, and appears to

\footnotetext{
${ }^{15}$ The Lisbon Treaty amended article six of the Treaty on the European Union (TEU), provided that the Charter is now legally binding, having the same status as the primary EU law, and that the EU 'will accede' to the European Convention on Human Rights (ECHR). See: S. Douglas-Scott, The European Union and Human Rights after the Treaty of Lisbon, Human Rights Law Review (HRLR) (11), 2011, pp. 645-682.

${ }^{16}$ G. Vermeulen \& W. De Bondt, First things first: Characterising mutual recognition in criminal matters, in B. De Ruyver, T. Vander Beken, F. Vander Laenen \& G. Vermeulen (Eds.), EU criminal justice, financial \& economic crime: new perspectives interest-based dispute resolution, 2011, p. 18.

${ }^{17}$ Since Lisbon, the Treaty on the Functioning of the European Union (TFEU) allows - in Article 82, 2. - for the establishment of minimum rules under certain conditions. See infra.

${ }^{18}$ Council of the European Union, Resolution of 30 November 2009 on a Roadmap for strengthening procedural rights of suspected or accused persons in criminal proceedings, 2009. Retrieved from http://eurlex.europa.eu/LexUriServ/LexUriServ.do?uri=OJ:C:2009:295:0001:0003:EN:PDF.

${ }^{19}$ Measures A to F: Measure A on (the right to) translation and interpretation, measure B on (the right to) information on rights and information about the charges, measure $\mathrm{C}$ on (the right to) legal advice and legal aid, measure $\mathrm{D}$ on (the right to) communication with relatives, employers and consular authorities, measure $\mathrm{E}$ on (the necessity of) special safeguards for suspected or accused persons who are vulnerable and measure $F$ on a green paper on (specific safeguards for/during) pre-trial detention. Own addition in brackets.

${ }^{20}$ Directive 2010/64/EU of the European Parliament and the Council of 20 October 2010 on the right to interpretation and translation in criminal proceedings, OJ 2010 L/280; Directive 2012/12/EU of the European Parliament and the Council of 22 May 2012 on the right to information in criminal proceedings, OJ 2012 L/142; Directive 2013/48/EU of the European Parliament and the Council of 22 October 2013 on the right of access to a lawyer in criminal proceedings and in European arrest warrant proceedings, and on the right to have a third party informed upon deprivation of liberty and to communicate with third persons and with consular authorities while deprived of liberty. OJ 2013 L 294.

${ }^{21}$ European Commission, The Right to... - a Fair Trial! Commission wants more safeguards for citizens in criminal proceedings. IP/13/1157 27/11/2013 [Press release], 2013. Retrieved from http://europa.eu/rapid/pressrelease IP-13-1157 en.htm.

${ }^{22}$ European Commission, Proposal for a Directive of the European Parliament and of the Council on procedural safeguards for children suspected or accused in criminal proceedings, COM(2013) 822 final, 2013. Retrieved from http://eur-lex.europa.eu/LexUriServ/LexUriServ.do?uri=COM:2013:0822:FIN:EN:PDF.

${ }^{23}$ European Commission, Commission Recommendation on procedural safeguards for vulnerable persons suspected or accused of criminal proceedings, OJ 2013 C 378/8. Retrieved from http://eurlex.europa.eu/LexUriServ/LexUriServ.do?uri=OJ:C:2013:378:0008:0010:EN:PDF.
} 
have been split along the faultline of its definition of vulnerability. While the Commission envisions a firm Directive on special safeguards for children suspected or accused of crime, thus specifically envisioning safeguards for vulnerable persons due to their age, disordered adult defendants will, at least for now, have to make do with the general Recommendation.

\section{A critical note on harmonising criminal procedures for vulnerable defendants: is the EU moving further away from a cross-border dimension?}

Before delving into the Commission's reasoning for this two-way approach, the general concept of introducing minimum standards for a specific category of defendants is to be assessed in terms of competency and feasibility. As indicated below, the previous measures and their subsequent Directives sparked a debate on the EU's power to do so. Yet, where these measures have each targeted a specific type of procedural right - information, translation, access to legal advice, etc. - applicable to a general public of people involved in criminal proceedings, the initiatives flowing from the Roadmap's measure E aim to enable a set of rights to a specified category of individuals based on their vulnerability. In order to legitimately do so, the Union should be clear in identifying how these initiatives would fall within the scope of competence bestowed upon it by its Treaties.

\section{1. The Procedural Roadmap and competence issues}

With the Lisbon Reform Treaty, the principle of mutual recognition was formally given a treaty basis in Article 82 of the Treaty on the Functioning of the European Union (TFEU). ${ }^{24}$ Simultaneously, Article 82(2) TFEU outlines the relation with minimum harmonisation of criminal procedural law. In its second paragraph, the article clearly states that (only) "to the extent necessary to facilitate mutual recognition of judgments and judicial decisions and police and judicial cooperation in criminal matters having a cross-border dimension, the European Parliament and the Council may, by means of directives adopted in accordance with the ordinary legislative procedure, establish minimum rules." This description of the Union's competence indicates a clear connection to mutual recognition for cooperation in criminal matters in a cross-border context as the guiding criterion for minimum rules to be established with a facilitating purpose. As such, the procedural roadmap's measures and their subsequent Directives sparked a debate on their context and scope of operation, as the minimum

\footnotetext{
${ }^{24}$ Art 82(1) TFEU clearly states that "Judicial cooperation in criminal matters in the Union shall be based on the principle of mutual recognition of judgments and judicial decisions and shall include the approximation of the laws and regulations of the Member States in the areas referred to in paragraph 2 and in Article 83.”
} 
procedural standards they contained and promoted moved beyond a strictly cross-border dimension and were also applicable in strictly domestic situations. ${ }^{25}$ With scholars hackling the Commission's methodological choices "betraying a cavalier attitude to the limits of EU competence in this area" leaving itself open to "criticism of creeping competence" 26 and stating that the current procedural rights debate has lost the link with cross-border situations ${ }^{27}$, it needs to be assessed whether or not the proposed Directive -as the most specific, binding outcome of measure $\mathrm{E}$ - focusing on specific safeguards for children will be "a bridge too far" ${ }^{28}$ in the sense of having lost a clear connection with the cross-border context.

\section{2. The proposed children Directive: Bending the rules...out of shape?}

With the proposed Directive for specific safeguards for children, the Commission specifically targets a group of vulnerable defendants who seem less likely to be involved in criminal proceedings in terms of cross-border cases. Articles 1 and 2 of the Proposal clarify the subject and scope of the Directive. On the one hand, it lays down minimum rules concerning certain rights of suspects or accused persons in criminal proceedings that are children. As such, the proposal seemingly moves beyond the notion of a strict cross-border context and simply targets any child involved in any kind (both domestic and cross-border) of criminal proceeding. On the other hand, the Directive specifically targets children subject to a surrender procedure pursuant to a European Arrest Warrant EAW. The latter, therefore, defines the specific focus of the Directive on children in situations where their arrest and surrender are requested by a member state after they have fled to another member state in order to evade prosecution or the execution of a custodial sentence or detention order. ${ }^{29} \mathrm{~A}$ critical observer may point to the fact that minors may face a considerable threshold - ready access to cash, credit and debit cards, means of transportation, driver's license, insurance, housing and accommodation opportunities, etc. - to effectively commit acts abroad resulting

\footnotetext{
${ }^{25}$ See, inter alia: W. De Bondt\& G. Vermeulen, The procedural rights debate A bridge too far or still not far enough?, Eucrim(4), 2010, pp. 163-167; Morgan, EHRLR 2012, pp. 427-432; R. Lööf, Shooting from the hip: Proposed Minimum Rights in Criminal Proceedings throughout the EU, European Law Journal (ELJ) 12(3), 2006, pp. 421-430; G. Vermeulen\& L. Van Puyenbroeck, Approximation and mutual recognition of procedural safeguards of suspects and defendants in criminal proceedings throughout the European Union. In M. Cools, B. De Ruyver, M. Easton, L. Pauwels, P. Ponsaers, G. VandeWalle, T. Vander Beken, F. Vander Laenen, G. Vermeulen\& G. Vynckier (Eds.), EU and International Crime Control, 2010, pp. 41-62; G. Vermeulen, Flaws and contradictions in the mutual trust and recognition discourse: casting a shadow on the legitimacy of EU criminal policy making \& judicial cooperation in criminal matters?, in: N. Persak (Ed.), Legitimacy and trust in criminal law policy and justice. Ashgate, 2014. (submitted book chapter, publication due in june 2014).

${ }^{26}$ Lö̈f, ELJ 2006, pp. $421 \& 426$.

${ }^{27}$ De Bondt \& Vermeulen, Eucrim 2010, p. 164.

${ }^{28}$ Ibid, p. 164.

${ }^{29}$ Article 1 of the Council Framework Decision 2002/584/JHA of 13 June 2002 on the European arrest warrant and the surrender procedures between Member States, OJ 2002 L 190.
} 
in a criminal offence with a cross-border dimension and the subsequent criminal proceedings and (mutual recognition of) the resulting judicial decisions. Truthfully, a similar observation ${ }^{30}$ could be made regarding vulnerable adults. Yet, where the causal relationship between a person's age and that person's capacity to travel and cross borders seems fairly straightforward, it is, however, much more ambiguous to automatically assume the same for a mentally and/or physically impaired adult. The variety - and perceptibility - by which mental and/or physical features may restrict an adult in his capacity to travel unhindered (or unnoticed) make this a less evident exercise. As the current initiatives only promote a proposal for a binding Directive for children, the specific reasoning for such an instrument, as well as the basis for EU competence in this matter, need to be scrutinised against the backdrop of the cross-border threshold. In the impact assessment accompanying the proposed Directive $^{31}$, the Commission has to admit that, in terms of cross-border cases, there is no precise information with regard to vulnerable persons arrested or prosecuted outside their own member state and that a $1 \%$ figure may be retained as representative of the cross-border cases concerning (all) vulnerable defendants. ${ }^{32}$ As such, the impact assessment's figures do not seem to make a particularly strong case for necessary EU action regarding children in transboundary situations. ${ }^{33}$ Both observations - the disconnection with a strict cross-border context in the first part of the definition of the Directive's subject and scope and the apparent limited practical use for an EU intervention in the area of European Arrest Warrants - raise the question as to which direction the EU is going with its procedural rights approach and which interpretation of Article 82(2) TFEU it upholds. The Commission's stance on this subject is clarified in the impact assessment, where it is said that the cross-border element is not (or no longer) the primary concern of the initiated proposal for the Directive. In a separate paragraph, aptly titled Does the EU have power to act?, it is stated that:

\footnotetext{
${ }^{30}$ This is not a mere personal assumption, but was also identified by the interim report on the study for the impact assessment of a measure covering special safeguards. The research team indicated that the approximations regarding the numbers of cross-border cased for vulnerable defendants were likely overestimated since minor delinquents or adult offenders may be less likely to travel outside of their place of residence than the general population. See: $G|H| K$., Impact assessment of a measure covering special safeguards for children and other vulnerable suspected or accused persons in criminal proceedings (Interim Report for the study just/2011/EVALJPEN/FW/1017/A4), DG Justice, 2012, p. 59.

${ }^{31}$ European Commission, COMMISSION STAFF WORKING DOCUMENT IMPACT ASSESSMENT Accompanying the document Proposal for a directive of the European Parliament and of the Council Proposal for a on procedural safeguards for children suspected or accused in criminal proceedings /* SWD/2013/0480 final */, 2013. Retrieved from http://eur-lex.europa.eu/legal-content/en/ALL/?uri=CELEX:52013SC0480.

${ }^{32}$ Ibid, p. 29, point 4.3. It is notable that the Commission (implicitly) acknowledges the arduous task of collecting solid information on vulnerable defendants in criminal proceedings throughout the EU, as is evidenced by the use of the woolly expression "data suggests".

${ }^{33}$ Moreover, in the interim report, the $G|H| K$ (fn. 30) research team does not address the "limited information vis-à-vis cross-border cases" like the Commission upholds, but that "little evidence has been found of vulnerable persons being arrested or prosecuted outside of their own member states".
} 
"This initiative will apply to all criminal proceedings irrespective of whether they present a cross-border element or not. The reason for this is that both the policy objectives as described below may only be met if minimum rules apply to all criminal proceedings. In order to improve mutual trust and thus judicial cooperation, judicial authorities need to be aware that sufficiently high standards apply across the board in the jurisdictions of other Member States. If Member States were at liberty to apply lower standards to purely domestic proceedings, the requisite of mutual trust between judicial authorities could not be boosted."34

Hence, the Commission seems to put its foot down in the ongoing debate on the necessary link with cross-border elements and mutual recognition of judicial decisions. With the cross-border element apparently no longer a prerequisite for the Union to intervene, the assessment document provides three patterns underpinning the EU's competence to act:

- First, the scope of Art 82(2) is applicable "not only to cross-border criminal proceedings, but also to domestic cases as a precise, ex ante categorisation of criminal proceedings as cross-border or domestic is impossible in relation to a significant number of cases." ${ }^{, 35}$

- Secondly, the citation above states that minimum standards are necessary on a domestic level in order to build up confidence and trust between judicial authorities in case of cross-border cooperation.

- Thirdly, an interesting point is made where the Commission states:

"As concerns the need to safeguard the fundamental rights of citizens, the enactment of minimum rules for cross-border proceedings only, far from addressing the problem, would create two different classes of defendants in criminal proceedings, one with more rights than the other; this distinction, made on the basis of the cross-border nature of the procedure, would lead to unreasonable differentiation and would eventually be detrimental to the protection of fundamental rights. In addition, when the matter is linked to EU law, the Charter guarantees rights to everyone suspected of a criminal offence, whether involved in cross-border or purely national proceedings." $" 36$

\footnotetext{
${ }^{34}$ European Commission (fn. 31), p. 31, point 4.5.1.,para. 2.

${ }^{35}$ Ibid, p. 31, point 4.5.1., para. 1.

${ }^{36}$ Ibid, para. 3.
} 
The first two statements tend to follow the type of classic reasoning previously witnessed in the preceding Directives. ${ }^{37}$ The first statement promotes the persuasion that it is better to be safe than sorry, and to prepare your domestic situation - i.e. justice system - up to an acceptable standard for when your criminal proceedings become of a cross-border nature. The second one follows a similar reasoning and aims to build up the trust necessary for smooth cross-border cooperation by working through a bottom-up method of inserting minimum standards on a domestic level, so that member states - when the time comes - will be able to be confident in each other's legal systems when issuing a cooperation measure. ${ }^{38}$ Very similar to the reasoning at the time of construction of the previous Directives, the question remains as to how this should and will be appreciated given the indication above that very few suspects or offenders who are minors find themselves entangled in cross-border criminal proceedings. The third statement, however, firmly moves away from the cross-border perspective and defends the more radical notion of more and better justice for all throughout the EU. ${ }^{39}$ The rationale for this is that confining the procedural minimum rights within a strict cross-border context would create a discriminatory context where individuals involved in domestic criminal proceedings may or may not be worse off. Moreover, the Commission makes a case for the notion that, as long as member states are acting within the scope of application of EU law, the EU's fundamental rights - via the Charter - are applicable regardless of a domestic or cross-border context. On both accounts, these are controversial arguments. In the first statement, the Commission implies that it no longer suffices to accept the diversity of (and between) the member states' internal criminal justice systems because they result in a discriminatory situation in which an individual, depending on the legal system applicable to him and whether or not he falls under a cross-border situation (and hence possible EU competence), is able to rely on either more or fewer rights. This seems poles apart from the equivalence idea $^{40}$ the Commission promoted at the start of the new era of cooperation in criminal matters where differences were acceptable because of the presupposed trust that a

\footnotetext{
${ }^{37}$ Comprising measures A to D (See fn. 19 \& 20).

${ }^{38}$ An in-depth debate on the merits of these claims would go beyond the scope of this article, but suffice it to say that the obviousness with which the EU links the introduction of procedural minimum standards to enhanced mutual trust and confidence is questioned. See, i.a.: Vermeulen(fn. 25).

${ }^{39}$ As is rightfully pointed out by Vermeulen (fn. 25), the 2009 Procedural Roadmap already made clear that the ambition of the instrument moved beyond 'fixing' trust issues in a cross-border mutual recognition context by stating in Recital 10 that "efforts should be deployed to strengthen procedural guarantees and the respect of the rule of law in criminal proceedings, no matter where citizens decide to travel, study, work or live in the European Union." As such, Vermeulen argues that more and better justice for all throughout the EU is the "real bet".

${ }^{40}$ European Commission, Communication from the Commission to the Council and the European Parliament Mutual recognition of Final Decisions in criminal matters, COM/2000/0495 final, 2000, point 3.1, para. $1 \& 2$. Retrieved from http://eur-lex.europa.eu/LexUriServ/LexUriServ.do?uri=CELEX:52000DC0495:EN:HTML.
} 
decision taken by a member state would always - throughout the diversity - adhere to an acceptable minimum (fundamental) standard. This may be understood in two ways: either the domestic standards fail to meet that presupposed minimum standard, therefore undermining the basic premises of mutual recognition and prompting an adequate response, or the Commission still considers the equivalence concept as intact, but wishes to push further for an EU-wide minimum harmonisation of criminal law beyond a cross-border context, therefore (out)stretching the competence interpretation of Art 82(2) TFEU. In the second statement, one cannot help but notice the ambiguity of the Commission's reasoning as it seeks to apply the CFREU beyond the condition that member states are acting within the scope of EU law. ${ }^{41}$ According to Article 51(1), the Charter is addressed to member states only when they are implementing Union law. ${ }^{42}$ The Court of Justice of the European Union (CJEU), in its 2013 preliminary ruling in the case of Åklagaren v. Hans Åkerberg Fransson confirmed that this covers all situations falling within the scope of Union law; ${ }^{43}$ hence, the Commission's statement that the Charter's provisions apply in both a domestic and cross-border context is viable. Before this can be the case, however, it has to be established that an EU legal act calls for national implementing measures and thus that the Union had the material competence to exercise and submit such a measure. ${ }^{44}$ As such, for the Commission, the sting is in the tail: on the one hand the delineated threshold for, and poor evidence of, cross-border situations involving vulnerable defendants puts pressure on the necessity (and therefore competency) to act under an Article 82(2) mandate. On the other hand, and more importantly, the Commission itself has made it clear that it wishes to apply a different rationale for introducing minimum standards for minors as vulnerable defendants, aberrant of Article 82's provisions. As such, the Commission wishes to derive a competency beyond the Treaty-based scope of Article 82(2) by referring to the provisions of the Charter of Fundamental Rights. Yet, this very instrument is applicable only in cases the EU has a legitimately established material competency to act in. Suffice it to say that a competency built on such circular reasoning has

\footnotetext{
${ }^{41}$ An extensive disquisition on the relationship between EU fundamental rights, ECHR, and member states' fundamental rights provisions may be found in: T. Marguery, European Union Fundamental Rights and Member States Action in EU Criminal Law. Maastricht Journal (MJ), 20(2013/2), 2013, pp. 282-301. Marguery (p. 282) clearly states that applying EU-fundamental rights to member states' actions is subject to the condition that member states are acting within the scope of application of the EU law.

${ }^{42}$ Literally, Art 51 (1) states: "The provisions of this Charter are addressed to the institutions and bodies of the Union with due regard for the principle of subsidiarity and to the Member States only when they are implementing Union law. They shall therefore respect the rights, observe the principles and promote the application thereof in accordance with their respective powers."

${ }^{43}$ European Court of Justice (ECJ) 26.2.2013, case C-617/10 (Åklagaren v. Hans ÅkerbergFransson), [2013] OJ C 114/08, para 19.

${ }^{44}$ Marguery, MJ 2013, p. 287.
} 
feet of clay. Whereas the EU's objective vis-à-vis procedural minimum rights is a noble cause in its own right, the fallacious competency discourse could thwart the entirety of the undertaking by culminating into a standoff on the principle of subsidiarity and the overstretch of EU power between the Union and the member states, not generally inclined to accept farreaching interference with regard to their own national laws and policies. ${ }^{45}$

\section{III.A brief look at the Commission Recommendation}

In order to fully grasp the Commission's progress in its quest for procedural safeguards for vulnerable persons suspected or accused in criminal proceedings, the Recommendation ${ }^{46}$ requires some brief assessment. In general, the instrument seems innovative in that it specifically aims at a presumption of vulnerability and the identification of such vulnerability in persons involved in criminal proceedings.

First and foremost, the Commission recommends member states to foresee a presumption of vulnerability for certain persons in their legal systems, as will be indicated in the chapters below; this presumption particularly focuses on vulnerability as a result of mental disorders and to a lesser extent physical impairments. ${ }^{47}$ Furthermore, it promotes the prompt and qualitative identification and recognition of such persons by ensuring that all competent authorities may have recourse to a medical examination by an independent expert, and that police officers, law enforcement and judicial authorities competent in criminal proceedings, should receive specific training to adequately deal with vulnerable persons. ${ }^{48}$ Apart from these novel suggestions, recommendations are made to ensure the right to medical assistance and the audio-visual recording of questionings. ${ }^{49}$ An intriguing aspect is that the Recommendation seems to draw from the English \& Welsh method where it promotes the presence and assistance of $\mathrm{a}(\mathrm{n})$ (appointed) legal representative or appropriate adult during police station and court hearings. ${ }^{50}$ A direct link with the cross-border context is made where the instrument

\footnotetext{
${ }^{45}$ A similar indication - at the time of the construction of the proposal for a Framework Decision on procedural safeguards - may be found in: $C$. Brants, Procedural safeguards in the European Union: too little, too late?, in: J. Vervaele (Ed.), European Evidence Warrant. Transnational Inquiries in the EU, 2005, p. 105.

${ }^{46}$ European Commission (fn. 23).

${ }^{47}$ Ibid, Recommendation 7 (under section 3). See infra chapter IV. B. on the link between this approach and the Commission's rationale vis-à-vis the absence of a workable definition for vulnerable defendants and mentally disordered defendants.

${ }^{48}$ Ibid, Recommendations 4 (under section 2) and 17 (under section 3).

${ }^{49}$ Ibid, Recommendations 12 and 13 (under section 3).

${ }^{50}$ Ibid, Recommendation 10 (under section 3). The added value of this explicit reference in the Recommendation is debatable, as the measures C\&D-based Directive already - at least partially - resolves the issue of legal representation and communication with relatives. For the England \& Wales connection, see Para. 3.15 of the Code of Practice for the detention, treatment and questioning of persons by police officers, available
} 
recommends that "the executing member state should ensure that a vulnerable person who is subject to European Arrest Warrant proceedings has the specific procedural rights referred to in this Recommendation upon arrest". 51

The identified recommendations have the potential to have a beneficial effect on the identification of a vulnerable person and thus ameliorate the procedural rights and effective participation in (cross-border) criminal proceedings. Nonetheless, further consolidation is needed given the general and vague nature of some of these suggestions. A minimum qualitative definition of an independent expert should be provided and the specific training needs to be specified and matched again with a qualitative threshold. The presumption of vulnerability still leaves too much room for interpretation as to how and where this presumption needs to be 'foreseen' and one may wonder whether generalising a certain member state's specific approach across the diverse European countries will be counterproductive. From the mental perspective - and one clearly envisioned as a primordial part of the presumed vulnerability according to recommendation seven - the immense variety by which mental disorders may impact on proceedings implies that additional safeguards in order to ensure the defendant's procedural rights will have to be more tailor-made. For now the biggest obstacle to effective results and improvements, however, remains the instrument's non-binding form. As a purely suggestive instrument, it leaves the addressees with the mere suggestion to report back and inform the Commission on the follow-up on the recommendations within 36 months of its notification. ${ }^{52}$

\section{IV.Establishing vulnerability through diversity and demonstrated needs. A plea for an adequate approach towards mentally disordered defendants}

Notwithstanding the critical observations above, the core of the initiatives - creating special safeguards for vulnerable defendants as a specific category of people involved in criminal proceedings in need of extra attention and defence opportunities - serves a noble goal. Apart from the discussion on the EU's ambiguous competency tactics, however, the policy choices made with respect to this goal need assessment. In the previous chapter, the Commission's Recommendation was evaluated on its flaws and merits, the biggest obstacle remaining its

via:http://www.homeoffice.gov.uk/publications/police/operational-policing/pace-codes/. On the appropriate adult provision see, i.a.: National Appropriate Adult Network, Appropriate adult provision in England \& Wales. Report prepared for the Department of Health and the Home Office, 2010. Retrieved from: https://www.gov.uk/government/uploads/system/uploads/attachment data/file/117683/appropriate-adultreport.pdf

${ }^{51}$ European Commission (fn. 23), Recommendation 16 (under section 3).

${ }^{52}$ Ibid, Recommendation 18 (under section 3 ). 
essentially non-binding character. The following paragraphs assess the Commission's rationale - based on three propositions - for its policy choices and make a case for an effective and adequate instrument for mentally disordered defendants. From a competency and policy perspective, such an instrument seems both feasible and imperative.

\section{IV.1. Vulnerability is in the eye of the beholder. Under identification of mental impairments in criminal proceedings}

Measure E aims to show special attention to suspected or accused persons who, due to age, mental or physical conditions, cannot understand or follow the content or the meaning of the proceedings. ${ }^{53}$ As such, the measure comprises a broad spectrum of possibly vulnerable defendants. The presented instruments, however, make a distinction from the start by delineating said vulnerability along the line of the age of the person involved. Up to a certain age limit, it is presumed (and for good measure: rightfully so) that every minor suspect or offender - with or without an additional mental or physical condition - presents a specific chance for vulnerability. Once this limit is reached, the specific mental or physical condition(s) from which a(n) (adult) person involved in criminal proceedings suffers need to be identified and assessed in order to establish this individual's vulnerability. Both evaluations, while undoubtedly influencing an individual's capacity to understand and participate in the proceedings, are based on considerably different grounds and hence require a diversified approach. When assessing an individual as vulnerable as identified by measure $\mathrm{E}$ in a strictly domestic context, the starting point will always be the screening and detection of said vulnerability once the individual has been apprehended. Hence, an immediate discrepancy becomes clear. Where a person's age consists of an objectified constatation ${ }^{54}$ and, similarly, a diminished capacity to equivalently participate in the proceedings due to a physical condition could be considered as being sufficiently objectionable ${ }^{55}$, the determination of a diminished capacity based on a mental condition still forms a contentious undertaking. ${ }^{56}$ To a large extent less distinct upon first sight and subsequently more complex to evaluate in terms of capacity and vulnerability, establishing the mental condition of a person involved in criminal

\footnotetext{
${ }^{53}$ Council of the European Union (fn. 18), p. 3, Measure E.

${ }_{55}^{54}$ E.g. Date of birth retrieved from birth certificate, passport, etc.

${ }^{55}$ E.g. Accessibility of the places where the proceedings take place, availability of adequately adapted accommodation during the proceedings, etc.

${ }^{56}$ In Annex II (Overview of stakeholder views on key elements of the proposed measures) of the impact assessment - European Commission (fn. 34) - accompanying the proposed Directive for special safeguards for children, the European Criminal Bar Association indicates the same conviction in its considerations where it is stated in para. 10 that "It is very difficult to define "vulnerable" except in relation to Children and Minors who may be identified by their age."
} 
proceedings- and acting accordingly - constitutes an exceptionally sensitive and complex exercise. Without compromising the vulnerability of suspects or offenders of minor age or with a physical impediment and by no means disclaiming their need for specific safeguards, it remains the case that the very starting point for establishing vulnerability remains much more problematic for (adult) defendants with a mental disorder. For one, various EU-wide studies have indicated the existing diversity, but also the substandard level, of the screening and detection mechanisms available in the member states' legal systems. ${ }^{57}$ Hence, from the starting point of an adequate establishment of vulnerability, an individual involved in criminal proceedings while subjected to a mental disorder, may be deemed as being in a disadvantageous position.

This lack of identification of adults with a mental disorder has a potentially grave impact on the data of vulnerable defendants in cross-border criminal proceedings. The scarcity of information ${ }^{58}$ on detected vulnerability due to a mental impairment combined with substandard screening methods and a general lack of identification imply, at least, the possibility of a much higher number of mentally vulnerable persons involved in cross-border proceedings that slip through the net. The observation that "overall, the shortage of evidence in the field of psychiatric prevalence and mental health care in prisons is nothing less than dramatic" and that "even the most rudimentary health reporting standards for mental health care in prisons are lacking almost everywhere in Europe" ${ }^{\$ 9}$ opens the door to gross neglect of mentally-oriented vulnerability both in domestic and cross-border context and both for juvenile and adult defendants. From a policy point of view, this necessitates prompt and adequate EU action in order to guarantee effective procedural safeguards. ${ }^{60}$ Moreover,

\footnotetext{
${ }^{57}$ There are no recent EU-wide results available on how (early) screening procedures in the pre-trial and trial phase are implemented across Europe, but the results of recent EU-wide studies indicating that qualitative screenings for mental disorders within European prisons do not take place in a consistent manner are an alarming indication. See, i.a.: G. Vermeulen, A. Van Kalmthout, N. Paterson, M. Knapen, P. Verbeke\& W. De Bondt, Cross-border execution of judgments involving deprivation of liberty in the EU. Overcoming legal and practical problems through flanking measures, 2011; G. Vermeulen, A. Van Kalmthout, N. Paterson, M. Knapen, P. Verbeke\& W. De Bondt, Material detention conditions, execution of custodial sentences and prisoner transfer in the EU Member States, 2011.; H. Dressing, H.J. Salize\& H. Gordon, Legal Frameworks and key concepts regulating diversion and treatment of mentally disordered offenders in European Union member states, European Psychiatry (EP),22(7), 2007, pp. 427-432; H. Dressing \& H.J. Salize, Forensic psychiatric assessment in European Union member states, ActaPsychiatricaScandinavica (APS), 114, 2006, pp. 282-289;E. Blaauw, R. Roesch\& A. Kerkhof, Mental disorders in European prison systems: arrangements for mentally disordered prisoners in the prison systems of 13 European Countries, International Journal of Law and Psychiatry(IJLP),23 (5-6), 2000, pp. 649-663; H.J. Salize, H. Dreßing, \& C. Kief, Mentally Disordered Persons in European Prison Systems-Needs, Programmes and Outcome (EUPRIS), 2007.

${ }^{58}$ This scarcity is lamented by all of the studies under fn. 57. See, i.a.: Salize, Dreßing\&Kief (EUPRIS), p. 6.

${ }^{59}$ Ibid, p. 71.

${ }^{60} \mathrm{~A}$ recent report of Fair Trials International - following research on the protection of fair trial rights across the EU - indicated that "there are inadequate safeguards in place to ensure that children, suspects with mental or
} 
contrary to the above mentioned issues surrounding the Directive for children inciting the Commission to boldly twist the Treaty based competence, the (scarcity of) statistics on mentally ill individuals seem to be in the Commission's favour. A potentially considerable group of (adult) individuals with a mental impairment involved in criminal proceedings remains undetected, even across the borders of the Union's member states. Hence, there would be no need to overstretch Article 82(2) TFEU's interpretation to vindicate EU action in this specific area.

\section{IV.2. The lack of an overarching definition for a vulnerable adult. A legitimate justification or a practical excuse?}

Notwithstanding this considerable part of the European population potentially remaining unidentified and insufficiently safeguarded, the Commission, in the Executive Summary of the Impact Assessment, explains its choice to stick to a recommendatory instrument by stating that the difficulty to determine an overarching definition - since there is no international or European legal instrument defining a vulnerable adult - and the existence of fewer relevant international standards and provisions for vulnerable adults ruled out taking legally binding action. ${ }^{61}$ While it is true - and alarmingly so - that there are no binding international or European norms and standards that specifically address vulnerable adults ${ }^{62}$, the impact assessment omits to clarify why this should result in a strictly non-binding Recommendation, despite the "rather lukewarm appreciation of the value of such an approach" 63 the assessment itself indicates ${ }^{64}$, just as it refuses to engage in an in-depth analysis, why the difficulty of a

physical conditions, or those who are otherwise vulnerable, understand the proceedings in which they are involved are treated fairly". See: Fair Trials International, Defence Rights in the EU, 2012. Retrieved from: http://www.fairtrials.org/wp-content/uploads/2012/10/ADR-Report_FINAL.pdf.

${ }^{61}$ European Commission, Commission Staff Working Document Executive Summary of the Impact Assessment Accompanying the Proposal for Measures on special safeguards for children and vulnerable adults suspected or accused in criminal proceedings, SWD (2013) 481 final, 2013, p. 7, para. 1. Retrieved from: http://ec.europa.eu/smart-regulation/impact/ia_carried_out/docs/ia_2013/swd_2013_0481_en.pdf.

${ }^{62}$ Not just defining them, but also vis-à-vis their screening and detection, procedural safeguards, accommodation, etc.

${ }^{63}$ The impact assessment - European Commission (fn. 31) - itself indicates little or no improvement or impact by working through a Recommendation. This unconvinced approach also struck the European Parliament currently assessing the Commission's initiatives and proposed Directive. See: A. Davies, Initial appraisal of a European Commission Impact Assessment European Commission proposal on procedural safeguards for children in criminal proceedings, Ex Ante Impact Assessment Unit, Directorate C for Impact Assessment and European Added Value, Directorate-General for Parliamentary Research Services (DG EPRS), European Parliament, 2014, p. 4. Retrieved fromhttp://www.europarl.europa.eu/RegData/etudes/note/join/2014/528785/IPOLJOIN_NT\%282014\%29528785_EN.pdf.

${ }^{64}$ Moreover, the fact that a first assessment of the progress made regarding the Proposed Recommendation would not be until three to four years following its publication indicates a lack of urgency to come up (back) with an adequate instrument, see: European Commission (fn. 61), p. 7. 
lacking definition should halter the construction of binding legislative initiatives, or why the option of defining the term vulnerable adult was discarded. ${ }^{65}$ Once again indicative of the assessment's employed spurious rationale, the European Parliament's Ex-Ante Impact Assessment Unit further wonders "why this difficulty [the lack of a definition] has not stopped other pieces of legislation already being adopted in the same field with specific provisions referring to vulnerable persons (e.g. Directive 2013/48/EU on access to a lawyer)" ${ }^{66}$ So rather than to seize the opportunity to (at least) investigate the viability of a common EU-wide understanding of vulnerability, the Commission suffices by stating that it is difficult and therefore unfeasible. ${ }^{67}$

In the Recommendation, somewhat paradoxically, the Commission itself seems to suggest a general definition for a vulnerable person by stating that such a vulnerable person is a "suspected or accused person who is not able to understand and to effectively participate in criminal proceedings due to their age, their mental or physical condition or disabilities. ${ }^{" 68}$ Yet, by already delineating a presupposed -due to general European consensus - vulnerability for children, this common definition would primordially focus on adults with either a mental or physical impairment. As aforementioned, the hiatus of a binding instrument comprises a particular risk for mentally disordered individuals as they consist of a less apparent and consistently under-identified population. In order to guarantee their procedural safeguards, an adequate presumption of vulnerability for this particular population is needed. The Commission would not have to start from scratch to create a presumption of vulnerability in a context of mental illness, as it may avail itself of already existing doctrines. Both the European Convention on Human Rights (ECHR) ${ }^{69}$ and the European Court's case law ${ }^{70}$, have spoken out regarding persons with an unsound mind. While the Court stated in its Winterwerp judgment that the Convention did not define what is to be understood as a person of unsound mind and that such a definitive description or interpretation cannot be given due to the

\footnotetext{
${ }^{65}$ Davies (fn. 63), p. 4.

${ }^{66}$ Ibid, p. 5.

${ }^{67}$ One can also not help but notice that, while indeed a general consensus on the age of majority vis-à-vis children exists and therefore the delineation of their vulnerability 'as children' is accepted, there still is great diversity between the member states' legal systems regarding the age for criminal accountability, the procedural elements regarding referral to (adult) criminal courts, etc.

${ }^{68}$ European Commission (fn. 23), Recital (1).

${ }^{69}$ Article 5, 1, e. ECHR states that "Everyone has the right to liberty and security of person. No one shall be deprived of his liberty save in the following cases and in accordance with a procedure prescribed by law: e. the lawful detention of persons for the prevention of the spreading of infectious diseases, of persons of unsound mind, alcoholics or drug addicts or vagrants".

${ }^{70}$ The European Court of Human Rights (ECtHR) has, since its Winterwerp ruling in 1979, consistently maintained its original views on the Convention's 'unsound mind' doctrine. See: Winterwerp v. the Netherlands, Application no. 6301/73, Judgement 24 October 1979.
} 
continually evolving concept of mental illness (and the society's attitude towards it) ${ }^{71}$, it does provide for certain safeguards such as the need for objective medical expertise to establish a true mental disorder before a competent national authority, the degree-threshold for a mental disorder to warrant compulsory confinement and the need for a disorder's persistence to validate a continued confinement. ${ }^{72}$ Departing from the notion that a definitive description of a mental disorder is neither feasible nor preferable, the EU should not hide behind it, but focus on creating awareness and recognition of vulnerability due to such a disorder. In the first place, this should be achieved through prompt, objective and qualitative identification of the latter, subsequently enabling the defendant's fundamental (procedural) rights. Once again in a conflicting, perhaps even perplexing rationale, the Commission does provide a suggestive definition of presumed vulnerability for "[in particular] persons with serious psychological, intellectual, physical or sensory impairments, or mental illness or cognitive disorders, hindering them to understand and effectively participate in the proceedings." ${ }^{, 73}$ On the one hand, dismissing any effective action on the subject as unattainable because of the definition crux, only to provide two workable definitions on the other, seems to imply a convenient, practicable reasoning by the Union, rather than one instigated by a legitimate cause to tackle vulnerability in a comprehensive manner. With these considerations in mind, it seems an inexcusable omission to leave - in particular - mentally impaired defendants without a legitimate and effective instrument simply due to the practical consideration that it would be an arduous task to do so.

\section{IV.3. The need for an integrated approach}

A final observation regarding the Commission's delineated approach between children and the 'bulk' of other vulnerable individuals, is that physical or mental impairment - unlike the distinction between a minor and adult defendant - is unrestricted by age. By creating a powerful instrument-to-be with the proposed Directive for minors while neglecting to do so on a general basis for all possible types of vulnerability, the Commission undermines the efficacy of the Roadmap's goal to create procedural safeguards for all vulnerable defendants, but also the proposed Directive itself. Once more with reference to the difficulty of detecting a - prevalent - mental illness, attributing vulnerability solely on an age criterion would forego

\footnotetext{
${ }^{71}$ ECtHR, Winterwerp v. the Netherlands (fn. 70), margin no 37.

${ }^{72}$ Ibid, margin no 39.

${ }^{73}$ European Commission (fn. 23), Recommendation 7.
} 
the reality that (juvenile) delinquency is often related to mental health related issues. ${ }^{74}$ By the same token, a relatively convenient establishment of a person's - be it of minor or adult age vulnerability due to physical incapacity could be made complex by coexistent mental illness. Hence, an integrated approach imposes itself in order to guarantee that all fronts are covered in guaranteeing necessary safeguards for the vulnerable population in criminal proceedings. The Commission's Recommendation, unrestricted by the age criterion of the proposed Directive, is satisfactory in this perspective, but ultimately remains a mere suggestive, nonbinding entity. An effective instrument is imperative to ensure an integrated approach towards vulnerability.

\section{Conclusion}

With the two new initiatives stemming from the Roadmap's measure E, the Commission embarks on a noble mission of enhancing the protection for a category of defendants in criminal proceedings that are specifically vulnerable due to age, mental or physical conditions. Rightfully aiming at providing better procedural safeguards, the Commission's policy choices and underlying rationale indicate a number of flaws with the potential to jeopardise the entirety of the set out goals. In the first place, the Commission risks overplaying its hand by flexibly interpreting Treaty and Charter-based provisions in order to establish a newfound type of - possibly overstretched - competence. Proposing legally binding legislation consisting of a set of procedural rights for an age-related category of persons less likely to be involved in cross-border criminal proceedings while justifying this approach through a newfound competence severed from the basis provided in the TFEU might just be the proverbial bridge too far for the member states. On the one hand, pushing the envelope competency-wise, the Commission in contrast seems terribly prudent when delineating its tactics to combat vulnerability in all its (other) aspects. Full attention is dedicated to children as vulnerable defendants due to the consideration that a widespread consensus already exists on their vulnerability, definitions and handling. The ascertainment by the Commission that no

\footnotetext{
${ }^{74} \mathrm{~A}$ large amalgam of reports is available on the link between juvenile suspects and offenders and mental health/mental illness. The International Juvenile Justice Observatory (IJJO) reports on the subject on a regular basis. For a voluminous and comprehensive European Comparative Analysis, see: International Juvenile Justice Observatory (IJJO), Mental Health Resources for Young Offenders - European Comparative Analysis and Transfer of Knowledge, 2008.

Retrieved from: http://www.ipji.org/fileadmin/data/documents/reports_monitoring_evaluation/IJJO_MentalHealthResourcesFor YoungOffendersVol1_2011_EN.pdf.
} 
binding international norms and standards directly deal with other vulnerable defendants, however, does not spark an in-depth comprehensive instrument, but prompted them to introduce an approach that in their own words has very limited potential of factually improving anything for the better on a procedural level. As a result, the choices made vis-à-vis the vulnerability policy leave a bitter feeling. Restricting the proposed Directive to children falls short of adequately tackling issues related to vulnerability throughout the EU, where, in order to justly deal with vulnerable subjects, an effective identification of their cause of vulnerability is necessary. A most pressing issue, and admittedly a complex one to grasp, is the overarching role of mental illness in a criminal context. Unrestricted by age, gender or physical capacity, mental disorder is often a coexistent stimulant for aberrant, possibly criminal behaviour that remains woefully under- or inadequately detected. Hence, there is a dire need to create additional safeguards as regards screening, detection and identification for both adults and children impaired by a mental condition as they tend to be less obviously visible and risk slipping through the net. By the same token, the problematic screening and detection - and as such, lack of identification - of mentally disordered adults in combination with a more probable cross-border mobility would imply that the creation of a binding instrument would be more in accordance with the terms of competency embedded in Article 82(2) TFEU. 